\title{
At 211 Monoclonal Antibody 81C6
}

National Cancer Institute

\section{Source}

National Cancer Institute. At 211 Monoclonal Antibody 81C6. NCI Thesaurus. Code C2490.

A radioimmunoconjug ate of a human-murine chimeric IgG2 monoclonal antibody (MoAb) 81C6 labeled with an alpha-emitting radionuclide Astatine 211 (At-211), with imaging and radioimmunotherapeutic properties. MoAb 81C6 recognizes the extracellular matrix antigen tenascin (hexabrachion), which is up-regulated in gliomas and other cancers. Using MoAb 81C6 as a carrier for At-211 results in the targeted imaging and/or destruction of cells expressing tenascin. 